\title{
A Theoretical Perspective on the Case Study Method
}

\author{
Zafer Çakmak $^{1} \&$ İsmail Hakan Akgün ${ }^{2}$ \\ ${ }^{1}$ Faculty of Education, Firat University, Elazığ, Turkey \\ ${ }^{2}$ Faculty of Education, Adıyaman University, Adıyaman, Turkey \\ Correspondence: İsmail Hakan Akgün, Eğitim Fakültesi, Adıyaman Üniversitesi, Adıyaman, Turkey. E-mail: \\ hakgun@adiyaman.edu.tr
}

Received: September 21, 2017

Accepted: October 9, 2017 Online Published: October 10, 2017

doi:10.5539/jel.v7n1p96

URL: https://doi.org/10.5539/jel.v7n1p96

This study was produced from a part of a dissertation titled "The Effect of Teaching Through Case Study Method on the Acquisition of Learning Outcomes and Retention of The Learning in the Course of 8th Grade Citizenship and Democracy Education" prepared by Ismail Hakan AKGÜN (2013) at the Department of Educational Sciences in Firat University under the supervision of Assoc. Prof. Zafer ÇAKMAK.

\begin{abstract}
Ensuring that students reach the determined goals of the courses at the desired level is one of the primary goals of teaching. In order to achieve this purpose, educators use a variety of teaching strategies and methods, and teaching materials appropriate to the content and the subject of the courses in the teaching process. As a matter of fact, it is known that the methods and materials that appeal to different sense organs of the students influence the learning process positively. In addition, the use of various teaching methods, techniques and materials in the teaching process both attract students' attention and save the lesson from boredom, which affects the learning positively. In the process of teaching students sometimes have problems using their theoretical knowledge in real life situations. In this context, various teaching methods are also used for the practicalization of theoretical knowledge in the teaching processes. The case study method is one of the effective methods to achieve this purpose, because the case study method is a teaching method that enables students to acquire the knowledge and skills to deal with the problem they are working on and to produce information-based solutions in real life situations similar to the situations they are working with. In this study, the literature related to the case study method was examined and the application of the method, its history, application types, points to be considered in the application process, advantages of using the method in the teaching process and its limitations and teaching techniques to be used with the method are explained.
\end{abstract}

Keywords: case study method, education, instruction, teaching methods

\section{Introduction}

Case study method is expressed in various sources with different terms such as case-work, case-method, plan game, simulation game and decision game (Hesapçıŏlu, 2011). By using case study method; it is ensured that the problems encountered in real life on a certain subject are examined and resolved in the classroom environment in the frame of cause and effect relations. Thusly, students are provided with the knowledge, skills and attitude related to the subject considered. In this manner, the case study method is a method used to help the students find effective solutions to problems they encounter in similar real life situations in a shorter time (Sünbül, 2010). In the implementation of this method, the students learn the event by studying the report about the case study, evaluate the problem by analyzing the data and bring various suggestions for the solution of the event by discussing the case study. In this method, students have the opportunity to learn by discussing, therefore they enjoy the method (Küçükahmet, 2009). The case study method requires high-level thinking skills (Armstrong \& Savage, 1990) and is highly effective in enhancing the conceptual understanding and motivation of the students (Dori \& Herscovitz, 1999). This method, along with providing students the basic qualities and skills they need in their daily lives, is a pedagogically helpful teaching activity (Demircioğlu, 2005). The case study method, which is appropriate for discovery learning (Cin, 2005; Demirel, 2009), contributes positively to the development of critical thinking, problem solving and decision making skills of the students (Bilen, 2006; Nas, 2006; Gözütok, 2011). The case study method is mostly applied in business circles, social work areas, 
medical sciences and education. The subjects to be used in this method should be selected from real life and should be in a way that help individuals who will work in this area develop affective characteristics (Bilen, 2006). It is possible to borrow cases from newspapers, magazines, television, scientific books, bibliographies, documentaries, news and movies as long as they are related to the content and goals of the courses (Sünbül, 2010). It should be preferred that cases that will be implemented in the classroom should be selected from actual events, however, if there is no available case related to the classroom activities or topic of the lessons, the cases that will provide the necessary experiences to the students can be created in a way that does not contradict with the logic (Bilen, 2006). The cases to be used in the teaching process can be determined by the teacher and brought to class, or they can be selected from the events that students see and experience. When it is preferred to use cases that students observe or experience, it both increases the awareness of the students about the events around them and contributes to the permanent and high level learning because the students have to participate actively in the process. Cases can be examined with the participation of the whole class or by dividing the class into small groups. If the class is divided into groups, all the groups can work on the same case or they can be provided different cases (Gözütok, 2011). The case study method also helps to fill the gaps between theory and practice in learning and teaching environments through the application of pre-learned concepts and principles. In some schools, instruction is given in areas where the physical ability to perform a job such as car maintenance, repair, use, or construction of a new car is more important. For instance, educating students about actual events related to the traffic that they may encounter in real life, implementing theory and practice together can be more effective. In other schools, education can be given to teach students how to acquire abstract skills. In general, theories, principles, laws, regulations, criteria, etc., may be important in such schools. In this case, students may not always be able to bridge the gap between concepts, facts, principles and theories and real life. One of the methods that can be used to avoid or to solve this problem in teaching is the case study method. In order to reach the teaching objectives, in the implementation process of the case study method, the students are brought face to face with the events, cases, situations and problems taken from the real life or resembled real life in the classroom environment. Case studies are generally distributed to students as printed, but can also be given as homework. In this case, the students should come to classroom as prepared to discuss the topic. One of the most important benefits of this method is that students have a chance to practice what they have learned in real life situations. The case study method can help students to become active people by saving them from passivity, so that they can apply the concepts they learn and principles in real life (Sönmez, 2007).

Another method similar to the case study method is the "research case study" method. This method, which is mostly used for the education of the administrators, is applied in the following five stages (Demirel, 2009):

1) The case is briefly explained to the participants,

2) The data related to the case is collected,

3) Identify possible solution strategies for the decision,

4) The decision that all of the working group agree on is made,

5) Assessment is carried out by examining the way of decision making, the applicability of the decision at work, and available opportunities.

Below, the history of the case method, its types, the points to be considered in applying the method, the advantages of the method, the limitations and the teaching techniques that can be used together with the case method are given.

\section{The History of Case Study Method}

This method has been used since ancient times in the education and training processes in different fields. In Sumerians, who lived B.C, history lessons were taught using case study method. The ancient Egyptians wanted the students to know about the events that had taken place and learn lessons from these events. Likewise, the Hebrews intended to teach the students some lessons by using short stories. The method of case study was used in education by the Persians, Arabs and Ottomans. In ancient Greece, the heroism of warriors, tales, epics, and legends were passed on to the young students, verbally and in writing, and discussions were held on the events that took place on these stories. This method has also been applied in the eastern world in India and China (Alacapinar, 2008).

The case study method was first used as an educational tool in law and business courses (Herreid, 2005a). This method was used by some law professors at the University of Harvard in the late 1800s and in different disciplines in the next few years (Giordano, 2009). Significant progress has been achieved since then about case studies (Herreid, 2005b). Lawyers have worked on case studies from the primary sources for which judges write 
their decisions as a result of the judgments, thus aiming to increase the practical courage and academic knowledge of their students and to provide them the necessary skills in their profession (Giordano, 2009).

In this context, realistic stories with good and bad practices are analyzed by teachers and students in the field of law and business. These stories have an educational message. In medical schools, the case study method was used in connection with problem-based learning at McMaster University in Canada and it is thought to have spread to the world from here (Herreid, 2005c, 2005d). First used as a lecture method in 1940s (Herreid, 1998), the case study method is widely used in social and science fields today.

\section{Types of Cases}

Case studies can be applied in different ways. Sönmez (2007) and Alacapınar (2008), which collected the case studies under two headings as "the case in general" and "the case as a form of presentation", explain them as follows:

\subsection{The Case in General}

This category of case studies has several types as full text, abbreviated case study, irregular case study, missing text, interaction situation and successive case studies. Information on these topics is given below.

\subsubsection{Full Text Case Study}

In this case, the given case has all the information that the students need and they do not have to research or apply to different sources. For example, when trying to give students the target behaviors related to "village administration", the real problems encountered by the village managers in the management process, the organizational structures of the villagers, what the problems are and how they occur, related people and their way of perceiving the problems should be included in the case study. Full text case studies can be eight to fifteen pages long depending on the subject. Because of this length, it can take a long time to analyze case studies. In this application, students may be asked to read and analyze the sample case, to make a decision, and to discuss their decision with their friends.

\subsubsection{Abbreviated Case Study}

In this type of case, students can only deal with a problem or work on a limited scenario. The length of the text can range from one paragraph to several pages. In this case, the scope of the case may be narrowed. Due to the short text of the case study, attention can be shifted to a limited point or to a single point; the solution of the problem or solution strategies may be limited.

\subsubsection{Irregular Case Study}

During the application of the irregular case study, all the information that the students need about the topic is given to the students in a complex structure rather than in a specific system or order, and students are expected to solve the problem by putting together this case as a meaningful piece.

\subsubsection{Missing Text Case Study}

In this kind of case study, where limited information is given to the students, students should ask for the necessary information to solve the problem. If the students do not want the necessary information from the teacher, the teacher should not make any explanations. In this case study, the teacher should ask the students to decide or act on a brief case. The missing text case study should be organized and used to ensure that students ask the right questions, analyze and solve the problem.

\subsubsection{Interaction Status Case Study}

In this case study, information on the subject is given to the students as incomplete. Students are expected to collect additional information they need to solve the problem by applying to the necessary resources, persons or institutions. This type of case study can be used more effectively in the process of preparing a research project.

\subsubsection{Successive Case Study}

In this case study type, the process starts with giving the information about the topic to the students as a limited piece of information. Once the sample information pieces are examined and processed, the students are asked whether they want additional information or not, and if necessary, the process is continued with additional information as required.

\subsection{Case Study As a Form of Presentation}

In addition to the sample events presented or given as printed, there are sample events presented orally such as games, movies, slides and pictures. These can make the course more remarkable. For example, when a topic for 
a problem is being presented, the presentation can be cut at the most important point and questions such as "What can be the next, and why?" can be asked and discussed on the subject. Then the result of the visual can be shown by using the result of the discussion. In this case, the debate about whether the answers to the questions asked in the discussion process about the topic is appropriate should be repeated.

\section{Considerations in the Implementation of Case Study Method}

Based on the subject and the goals of the courses, cases that are taken from the real life or is likely to be experienced in real life and that will attract the attention of the students (Taşpınar, 2005) should be determined and clearly written in accordance with the cognitive developments and levels of the students (Küçükahmet, 2009). The language used in the case should not be in a complex structure and students should be able to understand what they are reading. Reading comprehension is a process that involves making logical connections, interpreting text correctly, and applying information (Dönmez \& Yazici, 2006). Afterwards, the text of the case should be provided to all students, and the working conditions and the completion time of the work should be determined (Savaş, 2010). At the beginning of the course, the case should be briefly explained to the students in about five minutes, and then applied later (Hesapçıŏlu, 2011).

In order to be able to benefit from the case study method efficiently at the desired level, it is necessary to pay attention to the following points in the implementation process of this method (Cin, 2005; Demirel, 2009; Küçükahmet, 2009; Demirel, 2010; Sünbül, 2010; Gözütok, 2011).

- The subject and content of the case should be appropriate to the subject and the goals of the courses, the age, the level of cognitive development and readiness of the students.

- It should be ensured that the selected cases are of a nature that can be discussed by the students.

- The subject considered in the case study should be a basic problem that has been thoroughly analyzed and understood sufficiently.

- In the case to be handled, issues such as if the case is real, if it is meaningful, if it has an integrity and if it logically provides a different perspective should be carefully determined.

- The text of the case should be written clearly according to the level of the students.

- Preliminary information that students are required to to make their expected work on the case should be provided.

- I should be ensured that students understand the case well and correctly so that they are able to benefit from the case study method at the desired level.

- The questions to be directed to the groups in order to guide the group discussions on the case, to reveal the thoughts about how the case happens and the results of the case, and to determine the appropriate principles for the case should be prepared in advance and the time to ask these questions should be well planned.

- The teacher should ask various questions to guide the discussion about the case in the desired direction.

- In discussions about the subject, students should be prevented from entering the different subjects by moving away from the subject and the goals of the lesson, and it should be ensured that the students behave according to the discussion rules during the discussion process.

- Students should be followed up periodically to ensure that students are progressing in the right direction.

- At the end of the process, the whole evaluation of the subject should be done together with the students.

- At the end of the process, the determined principles and solutions should be evaluated and how to use these principles when encountered in similar cases should be discussed.

- The school administration should be informed in advance if it is a sensitive issue that is open to debate.

\section{Advantages of Using Case Study Method in Teaching Process}

Using case study method in the teaching process has many advantages. These advantages are expressed as follows (Cin, 2005; Bilen, 2006; Demirel, 2009; Küçükahmet, 2009; Gömleksiz, 2006; Alacapınar, 2008; Savaş, 2010; Sünbül, 2010, http://www.egitim.aku.edu.tr/metod02.htm):

- The case study method is a student-centered strategy that enables the student to be active rather than passive.

- It is a method for real life, in which students have the opportunity to put into practice their abstract thoughts by embodying them. 
- With this method, students develop skills such as sophisticated and independent thinking, producing original ideas and constructive discussion.

- In this method, because the students are interested in a specific problem, they are more interested in and motivated towards the lesson.

- Students have the opportunity to benefit from different materials and sources in addition to textbooks, thus, they are more interested in the topic.

- This method allows students to work cooperatively in communication with each other.

- Because case studies are often taken from real life situations, they are concrete, and it is easier to learn concrete facts.

- In real life, some cases have risky aspects. Because case studies do not have these risks and because the students have the right to correct their mistakes without risk, they can be more relaxed and unique. They can work on the case repeatedly until they solve the problem.

- Students who work on a case intensively do mental activities. Thus, they can reach the application, analysis, synthesis and evaluation stages of Bloom taxonomy. In this context, students may develop abilities of problem solving, abstract thinking and producing original knowledge.

- Because students have the opportunity to work collaboratively, they can develop discussion, collaboration and social skills.

- By working on case studies, students can develop multidimensional and critical thinking skills by learning the existence of different solutions to a problem.

- Students working on solving a problem in a case study can see how their previous knowledge works and when they cannot solve the problem, they can try to overcome these deficiencies by noticing the missing information.

- Students who face the same or similar situations in real life with as the case can make faster, correct decisions and take responsibility for resolving the problem. Thus, the risk may decrease and students' level of self-confidence may increase.

- Students can anticipate some problems they may encounter in real life and attempt to solve the problem without falling into pessimism as they face these problems.

- With this method, students may develop the ability to identify and limit the problem, set up solutions for the problem and solve the problem by finding appropriate methods. In other words, students may develop scientific thinking, scientific study and research skills.

\section{Limitations of the Case Study Method}

While every method used in the teaching process has many advantages, they may have some limitations as well. The limitations of teaching by case study method are as follows (Alacapınar, 2008; Küçükahmet, 2009; Sünbül, 2010; http://www.egitim.aku.edu.tr/metod02.htm):

- Preparing case studies takes a relatively long time and can be difficult to implement in crowded classrooms.

- Case studies require teachers to make good preparations before application.

- In situations where the teacher is unable to lead the group, another lead is needed who knows the case and the course objectives in detail.

- Challenges may arise in managing and evaluating debates in the classroom environment.

- It is not possible to achieve learning and teaching objectives if the students are not at a sufficient level of background knowledge and ability about the subject.

- It may be difficult to find or write a case that is fully relevant to the topic and the subject of the course.

- If the case does not match the level of cognitive development and readiness of the students (for example, to explain international rules of law to the 2nd graders), students cannot produce healthy ideas and discuss topics and this can adversely affect students' self-esteem.

- If the case is not well analyzed in the implementation process, it is not possible to transfer the results to real life. This situation can cause students to take unnecessary risks and fail to solve the problem in real life situations. In this case, students may have material and moral losses. 
- While working on case studies, students do not encounter real risks, so they can make haste decisions without thinking too much about the subject and apply those decisions. In such a case, the students will not have serious losses in the education process; but students can behave in this way thinking that this is the case in real life, which can cause many problems.

- All information necessary to solve the problem in the school setting can be given to the students by the teacher, but in real life, this may not be possible, because in real life information is not always readily available and students may need to find out the information they need to solve the problem. Problems may also occur in these situations.

- Students' perspectives on problematic events, their preliminary knowledge and prejudice can force or prevent the solution.

- Generally, because cases that are unethical and cause feelings such as, violence, fear, hatred, etc., cannot be brought to class according to some educational settings, students may perceive that the real life is fearless, non-violent, etc., and therefore they cannot see the real life in all aspects.

- Case studies in some subjects can be as long as fifteen pages long, and processing of such case cases can take a very long time to last for days. In this case, the students may be able to get help from outside the school or other people to solve the case problems, or they can act as if they solved themselves by solving all of these problems. This situation is very disadvantageous in the education process and is an undesirable phenomenon. Moreover, the fact that case studies are so long can cause students to move away from the subject, reduce their desires, their motivation and their attendance. In order to avoid such situations, the case study can be presented in pieces by cutting it from its important places; but this may also cause students not to see it as a whole.

All of these are among the limitations of the case study method.

\section{Techniques That Can Be Used Together with the Case Study Method}

It is known that teaching methods appropriate to the course, subject and the course objectives and the use of various teaching techniques together with these methods have a positive effect on learning in the teaching process.

Since the case study method is a method used in the strategy of discovery learning, various learning-teaching techniques can be used together with this method. While there are various types strategies, some of the most important ones are small and large group discussions, open ended question-answer, circle, opposite panel, debate, workshop, brain storming, problem solving, cooperative learning and decision making (Sönmez, 2007). In addition to these, many student-centered teaching techniques can be used together with the case study method (Küçükahmet, 2009; Sünbül, 2010).

\section{References}

Akgün, İ. H. (2013). Sekizinci Sinıf Vatandaşlık ve Demokrasi Ĕgitimi Dersinde Örnek Olay Yöntemiyle Öğretimin Öğrenme Düzeyine ve Kalıcılığa Etkisi. Yayımlanmamış Doktora Tezi, Fırat Üniversitesi, Eğitim Bilimleri Enstitüsü: Elazı̆g.

Alacapınar, G. F. (2008). Örnek Olay Yöntemi ve Eğitim İçin Örnek Olaylar. Ankara, Türkiye: Anı Yayıncılık.

Armstrong, D. G., \& Savage, T. V. (1990). Secondary Education (2nd ed.). New York: Macmillan Publishing Company.

Bilen, M. (2006). Plandan Uygulamaya Öğretim (7. Baskı). Ankara: Türkiye: Anı Yayıncılık.

Cin, M. (2005). Hayat Bilgisi ve Sosyal Bilgilerde Kullanılabilecek Strateji, Yöntem ve Teknikler (Tanrı̈rren, A., Ed., ss. 119-164). İstanbul: Lisans Yayınc1lık.

Demircioğlu, İ. H. (2008). Türkiye'de Tarih Öğretimi Aktif Vatandaşlık Eğitimini Desteklemekte midir? Türk Tarih Öğretmenlerinin Görüşleri. In M. Safran, \& D. Dilek (Eds.), 21. Yüzyılda Kimlik, Vatandaşlık ve Tarih Ĕgitimi. İstanbul, Türkiye: Yeni İnsan Yayınevi.

Demirel, Ö. (2009). Öğretim İlke ve Yöntemleri Öğretme Sanatı (15. Baskı). Ankara, Türkiye: Pegem Akademi Yayıncilik.

Dönmez, C., \& Yazıc1, K. (2006). The strategies and techniques that can be used according to text structure in improvement of students' reading comprehension skills in social studies MANAS. Journal of Social Research, 16, 137-154. 
Dori, Y. J., \& Herscovitz, O. (1999). Question-posing Capability as an Alternative Evaluation Method: Analysis of an Environmental Case Study. Journal of Research in Science Teaching, 36(4), 411-430.

Giordano, G. (2009). Solving Education's Problems Effectively a Guide to Using the Case Method. Published in the United States of America.

Gömleksiz, N. (2006). Öğretimde Strateji, Yöntem ve Teknikler (ss. 135-168). In M. Gürol (Ed.), Öğretimde Planlama ve Değerlendirme (4. Baskı). Ankara, Türkiye: Akış Yayıncılık.

Gözütok, D. (2011). Öğretim İlke ve Yöntemleri (3. Bask1). Ankara, Türkiye: Ekinoks Yayınevi.

Güven, M. (2011). Öğretme-Öğrenme Süreci (ss. 151-264). In B. Duman (Ed.), Öğretim İlke ve Yöntemleri (2. Baskı). Ankara, Türkiye: Anı Yayıncılık.

Herreid, C. F. (2005b). The Interrupted Case Method. Journal of College Science Teaching [e-book]. Retrieved November 29, 2012, from http://www.nsta.org/publications/news/story.aspx?id=51003

Herried, C. F. (2005a). Using Case Studies to Teach Science. Amerikan Institute for Biological Sciences, Electronic Journal Website.

Herried, C. F. (2005c). Using Case Studies to Teach Science. Amerikan Institute for Biological Sciences [e-book]. Retrieved November 29, 2012, from http://www.actionbioscience.org/education/herreid.html

Herried, C. F. (2005d), The Business End of Cases. Journal of College Science Teaching [e-book]. Retrieved November 29, 2012, from http://www.nsta.org/publications/news/story.aspx?id=51145\&print=true

Hesapçığlu, M. (2011). Öğretim İlke ve Yöntemleri, Eğitim Programları ve Öğretim. Ankara, Türkiye: Nobel Yayın Dağıtım.

http://www.egitim.aku.edu.tr/metod02.htm

Küçükahmet, L. (2009). Öğretim İlke ve Yöntemleri (23. Baskı). Ankara, Türkiye: Nobel Yayın Dağıtım.

Nas, R. (2006). Hayat Bilgisi ve Sosyal Bilgiler Öğretimi (3. Baskı), Bursa, Türkiye: Ezgi Kitabevi.

Savaş, B. (2010). Öğretim Yöntemleri. In M. Aslan (Ed.), Öğretim İlke ve Yöntemleri (3. Bask1). Ankara, Türkiye: Anı Yayıncilık.

Sönmez, V. (2007). Program Geliş̧tirmede Öğretmen El Kitabı (13. Baskı). Ankara, Türkiye: Anı Yayıncılık.

Sünbül, A. M. (2010). Öğretim İlke ve Yöntemleri (4. Baskı). Konya, Türkiye: Eğitim Kitabevi.

Tanrı̈rren, A. (Ed.). Hayat Bilgisi ve Sosyal Bilgiler Öğretimi (ss. 119-164). İstanbul: Lisans Yayınc1lık.

Taşpınar, M. (2005). Kuramdan Uygulamaya Öğretim Yöntemleri. Elazı̆̆, Türkiye: Üniversite Kitabevi. Retrieved November 27, 2012, from http://www.egitim.aku.edu.tr/metod02.htm

\section{Copyrights}

Copyright for this article is retained by the author(s), with first publication rights granted to the journal.

This is an open-access article distributed under the terms and conditions of the Creative Commons Attribution license (http://creativecommons.org/licenses/by/4.0/). 